\title{
The Deviation of Society's Alcohol Process in the Context of the Modern Social and Economic Crisis of XXI Century's the Second Decade
}

\author{
Elena Evgenyevna Pismennaya ${ }^{1}$
}

Sergey Vasilyevich Ryazantsev²

Irina Sovetovna Karabulatova ${ }^{2}$

Marina Nikolaevna Khramova ${ }^{3}$

Anna Yurievna Lukyanova ${ }^{3}$

\author{
${ }^{1}$ Financial University under the Government of the Russian Federation \\ 2Institute of Social and Political Research of the Russian Academy of Sciences, 32A, Leninsky prospect, Moscow \\ ${ }^{3}$ North-Caucasus Federal University
}

Doi:10.5901/mjss.2015.v6n6s3p160

\begin{abstract}
A detailed analysis concluded that the economic crisis of the XXI century's second decade was unconventionally serious for the Russian population owing to the strengthening of West's economic sanctions that leads to the strengthening of deviation processes in the country. As a rule, the economic situation in Russia is powerfully has an effect on the quality of social life. The thesis that social stress and dissatisfaction with the external reality make a considerable contribution to the formation of negative deviation processes, first of all, in Russian the alcohol society is very widespread. On the basis of social polls, statistical data, mass media materials the authors analyze the present situation in Russia. Deviation processes are understood the movement and development of deviations with their various character of state changes deviant behavior. Deviance as a category classifies the state of a deviant (subject) who is involved in this or that deviation process, at the same time by a subject's alloprining in a certain type of the deviation process as deviant behavior. Alcoholization as the deviant process has its own history in Russia and in the world which has certain dynamics of demonstration.
\end{abstract}

Keywords: deviation processes, alcoholic and deviation process, Russia, social and economic crisis, alcoholic behavior.

\section{Introduction}

Today deviation processes are the actual poly vector problem of modern scientific knowledge all over the world. In the situation of global social and economic cataclysms of the second decade of the XXI century alcoholism and drunkenness are at the head of the world's problems rating. So, in France each inhabitant drinks 55,4 liters of wine a year, in Portugal 52,6 liters, in Italy - 51,1 liters, in Russia - 6,1 liters of wine (Medinsky, 2008, p. 267). As the American Psychiatric Association claims in the USA $13,8 \%$ of adults misuse alcohol or suffer from alcoholism. Losses from alcoholism terrify: if during ten years in Vietnam 56000 people died, than over the same period in the USA 250000 people have been killed by drunk drivers (Medinsky, 2008, p. 271). At the same time in Russia in 2004 a number of alcoholics is 1,6\% of the whole population or 2 million 369 thousand people, and in 2006 - 192854 persons (Medinsky, 2008, p. 272). In this regard there is the issue on the reasonableness of a stereotype of drinking Russia, but the country scale is so big that these small percentages from the total population are comparable to big settlements and cities of Europe. Alcoholic deviations are determined by the controversial basic social position of each individual, who is "included" in deviant relations, his dispositional behavior (Kleiberg, 2001). For example, in 1819 a doctor of Moscow K M Bril-Krammer in his work "On hard drinking and its treatment " noted the social reasons of alcoholism, specifying that most of alcoholics whom he knows got sick after the Patriotic war of 1812 when many of them lost their property and relatives (Dudkina, 2007).

Determinants of that alcoholization in Russia are derivative both from historical conditions of the country development, external stereotypes of perception of the country in the world, and from phenomena and processes defining specifics of the present period.

A variety of deviation-alcohol behavior of society members, in particular, delinquent, on the basis of which is a 
feature of violation or blocking the process of anticipating the future result of the actions which characterizes an individual, which is in extreme forms a criminal act, are almost always harbingers of alcoholization of society.

The studies of alcoholization processes of the population show the influence in socio-structural transformations on the development and strengthening of alcoholic practices and the inverse relationship - formation of social groups, on the basis of these practices in the social and economic crisis in the second decade of the XXI century. The study of sociostructural deformations of Russian and Soviet societies claims that marginalization, lumpenization of earlier sustainable social groups (Shirin, 2015), degradation of social structures, simplification and primitivization of social communications and a way of life are socio-structural consequences on people's alcoholization. In the course of deviation-alcohol processes there is transformation of the institutional structure, shadow and criminal practices connected with production and sale of illegal, forged, "shadow" alcohol are institutionalized.

\section{Materials and Methods}

The study methodology is based on an analysis of various deviation processes in society which are consistently developed by M. Weber, A. Dudkina, E. Durkheim, A. Zdravomyslov, K. Marx, V. Medinsky, R. Merton, P. Sorokin, S. Ryazantsev and other researchers who were studying social and demographic changes processes connected with alcoholization processes of the population of Russia, the countries of near and far abroad. Thus, the basic methodological constructs were concepts of social marginalization, social deviation, value conflict and socio-cultural reproduction. The results of sociological studies which were conducted in various years by the academic institutes and scientific centers of the AS, the USSR and the Russian Academy of Sciences, the centers of receiving marketing information and polls, various mass media materials, data from historical and documentary sources, belles-lettres and so on became the empirical base of the social study and demographic changes in a context of deviant-alcohol processes.

Despite a stable international stamp about Russian alcoholism, unlimited consumption of strong alcoholic beverages is not "national specifics" of Russians, and it is caused by the negative influence of transformational processes on the social structure of society and the pressure upon the psycho-moral aspect of a personality as a result which there is degradation on a qualitative potential of the country's population.

\section{Results}

Now the experts claim that an average russian adult drinks 14,5 liters of alcohol a year (Halturina \& Korotayev 2010). The main features of a present stage of the XXI century's beginning in the context of growing alcoholization factors are:

1) Reduction of prices to alcoholic products in the falling income and a standard of living;

2) Transformation of alcohol into one of the most available to all categories of the population;

3) Emergence economically and politically powerful social groups whose income directly depends on the income from alcohol realization, unlike the state, for which sale of alcoholic products is one of many lines of budget's revenues. In this connection first of all the young population experiences new forms of deviations (Türker et al, 1998);

4) Emergence of the dominating impact source on consumer's behavior of the population - advertisement and means of telecommunication. Means of modern advertising and television render the basic vodka myth about Russian national specifics and there is alcoholic practices habitualization (Nemtsov 2003; Glushkova 2009 \& Strizhkova, 2012). Thus, advertising alcoholic products is built with pronounced directivity or expressivity, powerfully influencing a potential consumer of alcoholic products: "Virgin wines - just delicious? Full - flavored wines at the best possible prices!" (the magazine «Elle», 2009. №8. with 114); «Bravo - Rather strong cocktails!» (the magazine «Cosmopolitan», 2010, № 5. page 37); «Yat (vodka) Quality on five1» (vodka advertizing - the magazine «Men s Health», 2010. № 11. p.86].

A famous expert in alcoholization of Russian society A.V. Nemtsov estimates real and indirect alcoholic loss of Russia at 30\% of annual amount of men death and 15\% - women (2003). Other authors (Millet \& Shkolnikov, 1999; Korotayev, Malkov \& Khalturina, 2005; Karger \& Basel, 2001; Makki, 2010 \& Room, 2010) also point to the connection of abnormally high Russian mortality and alcoholism

The study of socio-structural distinctions of alcohol consumption has found:

1) Existence of a generative shift: considerable differences of motives and a character of alcohol consumption by youth from the senior age groups;

2) Essential distinctions of a character of alcohol consumption inside the youth generation connected with prevalence of differentiation processes caused by the social and stratification structure change of Russian 
society.

1) So, generational specifics of youth consist in prevalence of hedonistic, entertaining and leisure value orientation and standard behavior models, and formation on their basis of alcoholic behavior models that is caused by socio-cultural characteristics of millennials generation and their orientation to pleasure life. The intra-generational structure is presented by strong and weak groups' life which models alcoholic behavior are opposite (to drink a lot- less, often - seldom, big - small single doses, do not pay attention to their health - care about their health, keep a healthy lifestyle, consumption by force of habit, boredom, with a psychotherapeutic purpose - rare prestigious consumption of expensive alcohol). Dependence on a young professional's education level and the success of his starting career have a significant impact on the choice of an alcoholic behavior model. Involvement of young people in the deviant-alcohol process causes application by producers of alcoholic products of specifically focused advertizing where a hedonistic aspect is prevailing. The appeal to emotions predetermines the choice of language means and in advertizing of alcoholic products too. Both in the Russian and in the English language the use of adjectives united by a seme "bringing pleasure" is frequency: delicious, full - flavored, rich, wine, smooth, fun loving beer, fine wine, great tasting wine.

Gender comparison shows that, despite the same with men social background, belonging of most women to a category of poor and needy people and big predisposition of a female organism to alcoholic abuse formation, women are socially steadier to alcoholization than men (Ridlon 1998). Heavy social and moral women responsibility for a family, voluntary readiness to accept bigger freight of poverty in comparison with other family members is the reason.

Long depressions as a result of tender deprivation distinctions in a family can be a substantial prerequisite of women alcoholization in these families (Ridlon, 1998). Cultivation of social models of motherhood and professional selfrealization can become the alcohol prevention among girls and young women.

It is known that alcohol actualizes work of the center of pleasure in the brain and therefore causes pleasant feelings each time demanding the increasing dose and causing a consumer's dependence. In a number of the countries thanks to the carefully created step-by-step alcohol policy there is the decreasing alcohol consumption, first of all, in the USA, France and Sweden. The level of alcohol consumption in the countries where a number of adherents of Islam is not less than $40 \%$ of a total number of the population is traditionally low (Room, 2010).

It is necessary to recognize that deviant-alcohol processes have the direct interrelation with corruption, shadow economy, crime (in its various forms), prostitution. Besides, in Russia as, however, and in other countries of the world, during the whole XX century a tendency of alcoholism rejuvenation was more and more obviously traced, and it became obvious to experts that the risk of its emergence is growing against the background of the increasing alcohol consumption. A special alarm is caused by the fact that alcohol abuse signs among teenagers who often consuming alcohol and for the first time diagnosed were considerably increased. At the same time involvement of these young alcoholic deviants in other deviant processes is also noted.

Any deviant-alcohol behavior assumes not only aspiration to destroy or displace a frustrating block in the identity structure of a deviant, but also concentration of the energy which is necessary for this plan implementation. From here there are such stereotypic representations that "When a man is drunk, he does not fear anything", "Drunkenness reveals what soberness conceals", etc. A character of deviant-alcohol behavior, orientation of a person's energy potential depend on: first, how he can overcome arising difficulties: by creative or destructive actions; secondly, how society stimulates social and innovative, creative actions of a personality. At the same time it should be noted that the continuing frustrations owing to chronic stresses caused by the long socio-economic crisis promote the flight from a severe reality to the illusory world of short-term wellbeing and relax which is formed under the influence of alcohol consumption. The public instability and mass marginalization of the population in the rough 1990s considerably stimulated both these negative tendencies, actualizing the issue in the opinion of the whole society, but not just experts of health care, researchers and politicians.

\section{Discussion}

The recent history of Russia, along with Ukraine, Belarus and the Baltic States has the demographic "cross" caused by prevalence of the use of alcoholic beverages (Room, 2010). As Nemtsov, Khalturinova \& Korotayev think there is the direct correlation between the strength of the most popular type of drinks and mortality of men of an active social age 40-59 years. (Nemtsov, 2003 \& Halturina \& Korotayev, 2010). The diagram obviously shows dependence between the death-rate and the level of alcohol consumption over 8 liters per man in a year (it is the threshold level which exceeding is critical for the country) figure 1 : 


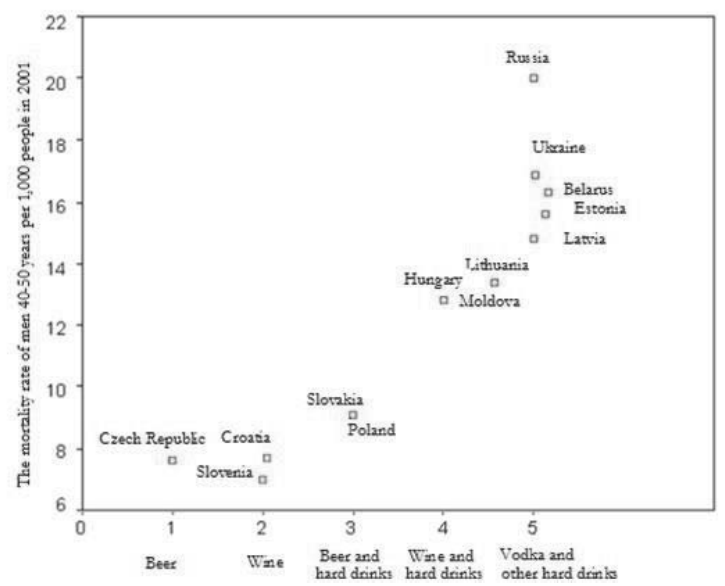

Figure 1 - The source on mortality data: UNICEF. The social monitoring "Innochenti", 2004 Florence, 2004

Alcoholic addiction is formed gradually and defined by complex changes which occur in an organism of a drinking person (Türker, 1998).

Besides, some authors emphasize the change of attitudes to alcoholic beverages and a character of their use owing to migration and globalization (Ryazantsev et al 2014), criticality decreases and a slang character of speech increases (Karabulatova, 2013; Karabulatova et al, 2015 \& Ryazantsev et al, 2015), the quality of life and the level of health decrease (Makki, 2010). For a long time deviant-alcohol processes belong to the sphere of public morals and in connection with their consequences for people around, despite essential cultural distinctions in perception of the alcoholic influence and is connected with it expected behavior models (Room, 2001).

\section{Conclusion}

The studies visually illustrate that the promotion to sobriety and moderation poorly influences people's behavior in respect of alcohol abuse. However, we consider that such promotion is necessary because it promotes formation of public support to the alcohol state policy. We think that the most effective measures of the alcohol policy are: a)alcohol availability segregation (especially it concerns strong alcoholic beverages) on price indicators, in space, on age of a possible buyer and in time; b) the fight against production and sale of "shadow" alcohol (vodka substitutes).

Russian alcoholization has a scenario of the same type by which other countries of the world are characterized. So, before the Revolution in 1917 alcohol consumption was significantly lower (by a factor of three) than now (Nemtsov, 2001, p. 5). For Russia the orientation to strong alcoholic beverages (first of all, vodka) which is characteristic for the northern countries became destructive that leads to life expectancy reduction and the increasing amount of death owing to murders against the background alcoholism and drunkenness, and also alcoholic intoxications.

\section{Acknowledgement}

A study supported by Grants of RFBR № 15-06-02854 A and 15-36-50205mol_nr.

\section{References}

Glushkova, T.A. (2009) Wine drinking stereotypes in alcoholic products advertisement. B: Herald of the Volgograd State University. Series 2. Science of language.№1. pp. 44-49.

Dudkina, O.V. (2007) Alcoholization of the population in Russia: socio-demographic consequences: thesis of a Candidate of Sociological sciences: 22.00.03 Novocherkassk.

Kleiberg, Yu.A. (2001) Deviant behavior psychology. M.

Korotaev, A.V., Malkov, A.S. \& Halturina, D.A. (2005) Laws of the history. Mathematical modeling of historical macroprocesses. Demography, economy, wars. M.: RUSS. 
Meletinsky, V.R. (2008) On Russian alcoholism, laziness and cruelty. M.

Millet, F. \& Shkolnikov, V.F. (1999) Death-rate in Russia: prolonged gap. B: World of Russia. Vol.VIII, №4 (24). pp. 138-162.

Nemtsov, A.V. (2003) Alcoholic loss of Russian regions. M.

Halturina, D.A. \& Korotaev, A.V. (2010) Introduction. Alcoholic accident: how to stop extinction of Russia. B: Alcoholic accident and possibilities of the state policy in overcoming of alcoholic supermortality in Russia. Moscow: URSS. pp. 5-58.

Karabulatova, I.S. (2013) The problems of linguistic modeling of new Eurasian linguistic personality in multilinguistic and mental environment (by example of onomasphere). In the: Middle-East Journal of Scientific Research 17 (6): 791-795.

Karabulatova, I.S., Khachmafova, Z.R., Bricheva, M.M., Nescheretova, M.T. \& Bersirova, A.K. (2015) Linguopragmatic Aspect of "Search for the Ideal" in the Discourse of Female Fiction as a Reflection of Matrimonial-Demographic and Sexual Behavior in Contemporary Russian Society. Review of European Studies. 2015. Vol. 7. No 6 (2015). pp.: 35-45.

Karabulatova, I. S., \& Kim, L.I. (2015). Socio-economic benefits of modern inclusive discursive practices in social rehabilitation with disabilities. Vestnik UGUES. Science, Education, Economy. Series: The Economy, 3(13), 54-59.

Karger A.G. \& Basel (2001) Alcohol per capita consumption, patterns of drinking and abstention worldwide after 1995. Appendix 2. In the: European Addiction Research. Vol.7, N3, p.155-157.

Makki, M. (2010) Health of Russianswhat is necessary to undertake to change a situation to the best. B: Alcoholic accident and possibilities of the state policy in overcoming of alcoholic supermortality in Russia. Moscow: URSS. pp. 138-151.

Ridlon, F.V. (1988) A Fallen Angel: The Status Insularity of the Female Alcoholic. Ontario.

Room, R. (2001) Intoxication and bad Behavior: Understanding Cultural Differencees in the Link. In the: Social Science and Medicine, \#53. pp. 189-198.

Room, R. (2010) Alcoholic policy: a situation and problems in Europe and Northern Asia. V.: Alcoholic accident and possibilities of the state policy in overcoming of alcoholic supermortality in Russia. Moscow: URSS. pp. 232-262.

Ryazantsev, S.V., Pismennaya, E.E., Karabulatova, I.S. \& Charif, Y.A. (2014) Transformation of sexual and matrimonial behavior of Tajik labor migrants in Russia. In the: Asian Social Science. Vol 10, No. 20. pp. 174-183.

Ryazantsev, S.V., Karabulatova, I.S., Mashin, R.V., Pismennaya, E.E. \& Sivoplyasova S.Yu. (2015) Actual problems of human trafficking in Illegal immigration in the Russian Federation. In the: Mediterranean Journal of Social Science. 2015. Vol 6, No3, S.1, May 2015. 621-626.

Türker, T., Sodmann, R., Goebel, U., Jatzke, S., Knapp, M., Lesch, K.P., Schuster, R., Schütz, H., Weiler, G. \& Stöber, G. (1988) High ethanol tolerance in young adults is associated with the low-activity variant of the promoter of the human serotonin transporter gene.

Shirin, S. S. (2015). Corruption in higher education in russia-first decade of the 21st century. International Education Studies, 8(2), 160168. doi:10.5539/ies.v8n2p160

Strizhkova, O.V. (2012) Specifics of communicative strategy realization in the advertizing discourse: on material of Anglo-and Russianspeaking advertizing of food: thesis of a Candidate of Philological sciences: 10.02.20 / Strizhkova Olga Valerevna; [Protection place: Chelyab. State. Ped. Un-y]. Chelyabinsk. 


\title{
Agro-industrial Clusters in the Russian Federation Economy: Features of Investment Attraction Analysis
}

\author{
Tatiana P. Maksimova ${ }^{1}$ \\ Konstantin V. Milyaev² \\ 1Plekhanov Russian University of Economics, Moscow, Russia \\ ${ }^{2}$ Moscow State University of Economics, Statistics and Informatics, Moscow, Russia
}

\section{Doi:10.5901/mjss.2015.v6n6s3p165}

\begin{abstract}
The present article reflects the authors' views on the subject of different approaches to explore features of changes in the agrarian sphere of economy. It is focused that an objective basis for an essential reformation in the agrarian sphere of national economy is to ensure national food security. One of the best ways to change the form and ways of economic management, according to the authors, is to create agro-industrial clusters in Russia. The writers believe that agro-industrial clusters have the potential to become under the modern circumstances an adequate response in choosing future paths to reform agrarian sphere of the Russian Federation economy considering the common inner instability within the country as well as the constantly changing foreign-economic challenges, including food sanctions. The article also introduces some theoretical aspects of creating agro-industrial clusters in the system of national economy; main features of agro-industrial clusters are determined. Special emphasis is placed on the exploration of the different issues of investment attraction and investment climate of agroindustrial clusters based on soil and climatic diversity of a region along with historically established distinctive features of economic management. Additionally, the article demonstrates a development of the authors' hypothesis of an official functionally structured modelling of investment attraction of regional agro-industrial clusters depending on both the analysis of common investment potential together with investment risks and economic situation in a single agro-industrial sector. Moreover, the writers suggests regional ranking of forming agro-industrial clusters in terms of investment attraction and the existing cluster initiatives.
\end{abstract}

Keywords: agro-industrial, investment attraction, investment potential.

\section{Introduction}

Difficulties of the whole process to create an agrarian sphere within the RF economy persuade researchers to search for the ways and methods of solving the existing problems, including scientific and theoretical grounds to accept optimal solutions while reforming. Recently more attention has been given to agro-industrial clusters acting as a determinant of a stable development of the agrarian sphere of national economy. While the scientific society continues controversy about the grounds of creating agro-industrial clusters, the choice of optimal organizational and structural models as well as alternative investment sources, this economic phenomenon gradually occupies a niche in Russian practical economic management. In 2015, for instance, in Novgorod Region, which in Russia historically belongs to poor soil zone, a largescale company called "Bristol, Ltd." has proceeded to implement the project on agro-industrial clusters (http://www.gks.ru/wps/, E-resource: Federal Service of State Statistics of RF). The Project has the support of regional government institutions. The investment volume of the project is calculated up to 620 million rubles. This agro-industrial cluster integrates within a single region not only in the sphere of agrarian industry, cattle breeding, including dairy and meet produce companies, but also simultaneous building such infrastructural assets as: housing, social and engineering structures. The creation of this particular agro-holding, like any other large-scale investment project, is graded. The startup period, which will last until 2016, focuses mainly on plant-growing producing, cultivating, stocking and processing potato in particular. It should be noted that the potato in Russia, according to some unspoken rule, is considered "second bread" and despite the technological changes people continue to plant it in their personal subsidiary plots (PSP) and their suburban plots (so called dachas). In this case two specifications are of special interest. Firstly, Western economies lack such form of economic management as Personal Subsidiary Plots (PSP) and suburban plots (dachas), which are based on the right of private land ownership. (Maksimova, 2013) Secondly, potato planting on one's own land for individual consumption and surplus sale on the market can be regarded as one of the deep-rooted traditions in Russia concerning 